\title{
HUBUNGAN BERAT BEBAN TERHADAP TINGKAT KEJADIAN NYERI PUNGGUNG BAWAH PADA PEKERJA BURUH ANGKUT PASAR LEGI SURAKARTA
}

\author{
Endang Sri Wahyuni \\ Poltekkes Kemenkes Surakarta Jurusan Okupasi Terapi
}

\begin{abstract}
Background: One part of the working community at high risk for low back pain is transport workers. This study aims to determine whether there is a heavy influence on the burden of the incidence of lower back pain in transport workers in Surakarta Legi Market. The sample of the study was 30 laborers in the Legi Market in Surakarta, all of whom were male and were taken by purposive sampling. The research instrument was a Visual Analogue Scale (VAS) pain scale questionnaire to determine the degree of pain. Methods: This research is a survey research with cross sectional approach. The method of data analysis in the form of Rank Spearman test using the SPSS statistical program.

Results: The results of Rank Spearman test obtained a value of $10.01 \%$ obtained count of +0.752 with a significance of 0,000. This shows that there is a relationship between the weight of the burden of lower back pain experienced by transport workers in Surakarta Legi Market. Conclusion: This study shows that there is a relationship between the weight of the burden of lower back pain experienced by transport workers in Surakarta Legi Market.
\end{abstract}

Keywords: Heavy Burden, Pain, Lower Back, Transport Workers

\section{PENDAHULUAN}

Masyarakat pekerja merupakan manusia tenaga kerja (naker) yang berperan sebagai pelaksana dalam berbagai sektor kegiatan ekonomi (Budiono, 1992). Agar kinerja para naker dapat optimal, maka diperlukan adanya pembinaan dan pengembangan ke arah produktifitas yang tinggi. Salah satu cara yaitu dengan meningkatkan status kesehatan, keselamatan, dan kesejahteraan naker dengan memasyarakatkan dan mengintegrasikan program keselamatan kerja dan ergonomi melalui penyelenggaraan kesehatan.

Kesehatan kerja dapat dicapai secara optimal jika tiga komponen kesehatan kerja berupa beban kerja, kapasitas kerja, dan beban tambahan akibat lingkungan kerja dapat berinteraksi secara baik dan serasi (Suma'mur, 1996).

Beban kerja dari setiap pekerja berbeda-beda, sesuai dengan jenis pekerjaannya. Beban kerja dapat berupa beban fisik, mental, dan sosial. Beban fisik ditemukan saat melakukan pekerjaan yang menggunakan fisik sebagai alat utama, seperti pekerjaan memindahkan beban. Berat beban yang diangkat dan frekuensi mengangkat saat bekerja dapat mempengaruhi kesehatan terutama kesehatan tulang belakang.

Berdasarkan hasil penelitian yang dilakukan oleh Suma'mur (1996) dalam higine perusahaan dan kesehatan kerja, menunjukkan bahwa angka sakit buruh/pekerja sehari-harinya sebesar 35\%. Angka tersebut kadang meningkat 
menjadi $8-11 \%$. Pada umumnya, angka kemangkiran kerja sangat tinggi sehingga waktu kerja hilang 3-10\%.

Pekerja buruh angkut adalah pekerja di pasar yang melayani para pedagang untuk bongkar-muat barang dagangan dengan imbalan jasa (upah). Pada umumnya pekerja buruh angkut menggunakan tubuh untuk mengangkat beban yang ada tanpa menggunakan alat bantu angkut seperti gerobak/kereta dorong.

Berdasarkan hasil survei awal yang dilakukan terhadap naker buruh angkut di Pasar Legi Surakarta, diperoleh informasi bahwa para buruh angkut biasanya mengangkat beban dengan rata-rata angkat sebesar $100 \mathrm{~kg}$ dalam sekali angkat. Mereka dapat mengangkat beban sekitar 2 ton dengan frekuensi angkat 10 kali. Hal ini bertolak belakang dengan International Labour Organization (ILO), yang menyatakan bahwa berat beban fisik maksimal sebesar $50 \mathrm{~kg}$ (Suma'mur, 1996). Disamping itu, terdapat pekerja usia dewasa yang mengeluh mengalami nyeri punggung bawah, nyeri pada tungkai saat bekerja, dan pekerja mengalami ketergantungan terhadap obat penghilang nyeri. Akan tetapi, terdapat juga pekerja yang tidak menghiraukan nyeri punggung bawah karena tuntutan perekonomian, sebab jika tidak bekerja maka tidak akan mendapatkan penghasilan untuk memenuhi kebutuhan hidupnya.

Berdasarkan latar belakang di atas, maka peneliti tertarik untuk melakukan penelitian mengenai hubungan berat beban angkat terhadap angka kejadian nyeri punggung bawah pada pekerja buruh angkut di Pasar Legi Surakarta.

\section{METODE PENELITIAN}

Penelitian ini merupakan penelitian survei lapangan dengan pendekatan cross sectional. Jenis penelitian non eksperimental dengan menggunakan observasi, survei, dan kuesioner. Tujuan penelitian, untuk mengetahui hubungan antara berat beban angkat pada pekerja buruh angkut di Pasar Legi Surakarta terhadap tingkat kejadian nyeri punggung bawah.

\section{HASIL PENELITIAN}

Subjek penelitian pada penelitian ini adalah pekerja buruh angkut di Pasar Legi Surakarta berjenis kelamin laki-laki, usia 25-40 tahun, bekerja lebih dari 5 tahun, mengalami tingkat nyeri 1-10 pada pemeriksaan Visual Analogue Scale (VAS), dan tidak mempunyai riwayat trauma/rematik serta penyakit tulang belakang yang lain. Jumlah subjek 30 pekerja.

Tabel 1. Umur

\begin{tabular}{ccc}
\hline $\begin{array}{c}\text { Umur } \\
\text { (th) }\end{array}$ & Frekuensi & $\begin{array}{c}\text { Presentase } \\
(\mathbf{\%})\end{array}$ \\
\hline 25 & 2 & 6.7 \\
26 & 2 & 6.7 \\
27 & 2 & 6.7 \\
30 & 5 & 16.7 \\
32 & 3 & 10.0 \\
35 & 3 & 10.0 \\
36 & 1 & 3.3 \\
37 & 1 & 3.3 \\
39 & 1 & 3.3 \\
40 & 10 & 33.3 \\
\hline Total & $\mathbf{3 0}$ & $\mathbf{1 0 0 . 0}$ \\
\hline
\end{tabular}

Sumber : Olah Data SPSS

Berdasarkan tabel 1, umur pekerja paling tua dan paling banyak adalah 40 tahun sebanyak 10 orang $(33,3 \%)$. Sedangkan umur paling muda 25 tahun. 
Tabel 2. Lama Kerja

\begin{tabular}{ccc}
\hline $\begin{array}{c}\text { Lama kerja } \\
\text { (th) }\end{array}$ & Frekuensi & $\begin{array}{c}\text { Presentase } \\
(\boldsymbol{\%})\end{array}$ \\
\hline 6 & 5 & 16.7 \\
7 & 2 & 6.7 \\
8 & 4 & 13.3 \\
9 & 4 & 13.3 \\
10 & 5 & 16.7 \\
11 & 1 & 3.3 \\
12 & 3 & 10.0 \\
13 & 2 & 6.7 \\
15 & 3 & 10.0 \\
16 & 1 & 3.3 \\
\hline Total & $\mathbf{3 0}$ & $\mathbf{1 0 0 , 0}$ \\
\hline
\end{tabular}

Sumber : Olah Data SPSS

Berdasarkan tabel 2, lama kerja minimal pekerja buruh angkut adalah 6 tahun dan maksimal 16 tahun. Rata-rata lama kerja pekerja buruh angkut adalah 6 dan 10 yang mencapai $16,7 \%$.

Tabel 3. Berat Beban

\begin{tabular}{lcc}
\hline $\begin{array}{l}\text { Beban } \\
(\mathbf{k g})\end{array}$ & Frekuensi & $\begin{array}{c}\text { Presentase } \\
(\mathbf{\%})\end{array}$ \\
\hline 60 & 1 & 3.3 \\
75 & 11 & 36.7 \\
80 & 6 & 20.0 \\
100 & 12 & 40.0 \\
\hline Total & $\mathbf{3 0}$ & $\mathbf{1 0 0 . 0}$ \\
\hline
\end{tabular}

Berdasarkan tabel 3, Berat beban yang diangkat oleh pekerja buruh angkut berkisar antara 60-100 kg dalam sekali angkat, dimana jumlah beban angkat terbanyak sebesar $100 \mathrm{~kg}$ sebanyak $40 \%$.

Tabel 4. Tingkat Nyeri Punggung Bawah

\begin{tabular}{lcc}
$\begin{array}{l}\text { Tingkat } \\
\text { Nyeri }\end{array}$ & Frekuensi & $\begin{array}{c}\text { Presentase } \\
(\boldsymbol{\%})\end{array}$ \\
\hline Ringan & 18 & 60.0 \\
Sedang & 11 & 36.7 \\
Berat & 1 & 3.3 \\
\hline Total & $\mathbf{3 0}$ & $\mathbf{1 0 0 . 0}$ \\
\hline
\end{tabular}

Sumber : Olah Data SPSS
Berdasarkan tabel 4, dapat diketahui bahwa pekerja buruh angkut yang mengalami nyeri punggung bawah ringan sebesar 60\%, nyeri sedang sebanyak $36,7 \%$, dan nyeri berat $3,3 \%$.

Tabel 5. Berat Beban dengan Nyeri Punggung Bawah

\begin{tabular}{lcc}
\hline \multicolumn{3}{c}{ Skor nyeri } \\
\hline Skor berat & $\mathrm{r}$ & 0,752 \\
beban & $\rho$ & $<0,001$ \\
& $\mathrm{n}$ & 30
\end{tabular}

Sumber : Olah Data SPSS

Berdasarkan paparan pada tabel 5 hasil analisis Rank Spearman menunjukkan bahwa terdapat korelasi yang bermakna antara berat beban dengan tingkat nyeri punggung bawah pada pekerja buruh angkut di Pasar Legi Surakarta. Nilai korelasi Spearman sebesar 0,752 menunjukkan bahwa arah korelasi positif dengan kekuatan korelasi yang kuat.

\section{PEMBAHASAN}

Hasil penelitian dengan menggunakan uji Rank Spearman dengan $\alpha 0,01 \%$ didapatkan $\rho$ hitung sebesar $+0,752$ dengan signifikansi 0,000. Sedangkan nilai $\rho$ tabel adalah 0,478 . Karena nilai $\rho$ hitung lebih besar dari $\rho$ tabel $(+0,752>+0,478)$ maka dapat disimpulkan bahwa terdapat hubungan antara berat beban dengan nyeri punggung bawah yang dialami oleh pekerja buruh angkut di Pasar Legi Surakarta. Nilai signifikansi menunjukkan 0,000 yang jauh di bawah 0,05 ini menunjukkan bahwa hubungan ini benar-benar signifikan.

Penelitian ini senada dengan hasil dari Risdianti (2018) tentang hubungan antara beban kerja dengan keluhan Low Back Pain (LBP) pada kuli panggul 

perempuan di Pasar Legi Surakarta. Penelitian kuantitatif, dengan design cross sectional. Teknik sampling dengan total sampling sebanyak 80 orang. Hasil kesimpulan yang didapatkan adalah ada hubungan antara beban kerja dengan keluhan Low Back Pain (LBP) pada kuli panggul perempuan di Pasar Legi Surakarta dengan $\rho 0,000$ dan r 0,414. Dimana $80 \%$ subjek penelitian mengalami nyeri sedang.

Hal ini didukung oleh teori, bahwa pemindahan beban secara manual yang berlebihan dapat mengakibatkan kecelakaan kerja yang berupa kerusakan jaringan tubuh (Nurmianto,1998). Hal tersebut dapat menyebabkan rusaknya struktur tulang belakang akibat adanya lumbosacral strain. Sebagai contohnya adalah pegal/nyeri dan difus, lumbago, skoliosis, fraktur kompresi, dan spondilosis ataupun spondilolistesis (Sidharta, 1984).

\section{KESIMPULAN DAN SARAN}

Kesimpulan dari hasil penelitian ini adalah peneliti menemukan hubungan yang signifikan antara berat beban yang diangkat dengan nyeri punggung bawah yang dialami oleh para pekerja buruh angkut di Pasar Legi Surakarta. Hal ini mungkin dapat diakibatkan oleh berat beban yang diangkat oleh pekerja buruh angkut di Pasar Legi Surakarta melebihi batas angkat secara legal yang telah ditetapkan oleh pemerintah.

Sebagian pekerja buruh angkut mengalami nyeri punggung bawah ringan sebanyak $60 \%$, nyeri sedang $36,7 \%$, dan mengalami nyeri berat $3,3 \%$.

Saran yang dapat diberikan: menerapkan batas maksimal berat beban angkat maksimal, segera memeriksakan diri jika merasa nyeri punggung bawah, tidak mengkonsumsi obat penghilang rasa nyeri/jamu secara berlebihan dan tanpa pengawasan dari dokter, menggunakan kereta dorong jika memindahkan beban lebih dari $50 \mathrm{~kg}$.

\section{DAFTAR RUJUKAN}

Budiono, A. M. S. (1992). Bunga Rampai Hiperkes \& Keselamatan Kerja. Surakarta: PT. Tri Tunggal Tata Fajar

Nurmianto, E. (1998). Ergonomi Konsep \& Aplikasinya. Jakarta: Guna widya

Risdianti, D. 2018. Hubungan Antara Beban Kerja Dengan Keluhan Low Backpain (LBP) Pada Kuli Panggul Perempuan Di Pasar Legi Surakarta. Surakarta: UMS: Fak. Ilmu Kesehatan

Sidharta, P. (1984). Neurologi Klinik Dalam Praktek Umum. Jakarta: PT. Dian Rakyat

Suma'mur. (1996). Higine Perusahaan \& Kesehatan Kerja. Jakarta: PT. Toko Gunung Agung 